\title{
Workplace and Lung Capacity of Petrol Gas Station Workers in Kendari City
}

\author{
Amiruddin Eso $^{1}$, Triaji Ariansyah ${ }^{2}$, Ela Martisa ${ }^{3}$ \\ \{amir_fk_unhalu@yahoo.co.id ${ }^{1}$, ariansyahtriaji@gmail.com ${ }^{2}$, ela.amiruddin@yahoo.com $\left.{ }^{3}\right\}$ \\ ${ }^{1}$ Faculty of Medicine, Halu Oleo University, Kendari, Indonesia \\ ${ }^{2}$ Medical Education Programme, Faculty of Medicine Halu Oleo University, Indonesia \\ ${ }^{3}$ Faculty of Cultural Science, Halu Oleo University, Indonesia
}

\begin{abstract}
This research aims to figure out the correlation of workplace and lung capacity of petrol gas station workers in Kendari City. An analitical study with samples of worker in Saranani, Bonggoeya and Martandu Petrol Gas Station consisted of 42 samples. Measurement of workplace identified using questionnaire and lung capacity is measured using spirometry. Data analysis used Statistical Chi Square test and signifficancy level at 0,05. The result showed 31 of 32 respondents $(96,9 \%)$ have abnormal lung capacity in outdoor and 2 of 10 respondents $(20 \%)$ at outdoor. There was a signifficant correlation of workplace to lung capacity of Petrol Gas Station workers ( $\mathrm{p}$ value $=0,00$ ).
\end{abstract}

Keywords: Lung Capacity, Petrol Gas Station Worker, Workplace.

\section{Introduction}

Outdoor air pollution is one of the main cause of death and disease in the world. An estimated 4.2 million peoples get death risk in the world are linked to outdoor air pollution. The health effects consisted of hospital admissions, emergency room visits and increased risk of premature death [1]. Chemical Hazard of petroleum product and its waste are causing the health problem mainly the symptom of respiratorius tract such as chronic cough, wheezing and dyspnu. Petrol gas station workers are exposed to the pollutant of petroleum product daily [2]. Total lung capacity is the maximum volume of air that the lung can inspired [3]. The short term effect of ambient concentration of nitrous oxide and ozone leading to the decreased lung function [4]. Many studies stated the role of particular matter consisted of liquid droplets and small particles to the decline of the function of lung in indoor workplace [5], however this research leads to investigate the association of outdoor and indoor workplace to lung capacity of petrol gas station workers in Kendari City. 


\section{Research Method}

An analitic observational study with cross sectional design. Samples of worker in Saranani, Bonggoeya and Martandu Petrol Gas Station consisted of 42 peoples held on March to April 2017. All of samples were less than 45 years old. Exclusive criteria of samples were smoker, chronic respiratory disease patient and cardiopulmonary disease patient. Measurement of workplace identified using questionnaire and lung capacity is measured using Winspro spirometry by profficient staff of Diagnostic Laboratory of Maxima Kendari. The results judged by Iwan Derma Karya, a specialist doctor of Pulmonology, Department of Pulmonology Faculty of Medicine, Halu Oleo University. Lung capacity of the workers categorized into normal and abnormal lung capacity according to Force vital capacity (FVC) and FEV1 parameters. Abnormal lung capacity consisted of restrictive pattern and obstructive pattern in spirometry devices. Data analysis using Fisher's Exact Statistical Test and signifficant level at 0,05.

\section{Results and Discussion}

The workers of Petrol Gas Station work in Saranani, Bonggoeya and Martandu Petrol Gas Station varieted on ages, but predominantly aged $19-25$ years $(45,2 \%)$. The males $(71,4 \%)$ more than females The details of characteristic of respondent showed at Table 1.

Table 1. Respondent characteristic based on age, gender, Body Mass Index, Self Protection Devices and working periods to lung capacity

\begin{tabular}{|c|c|c|c|c|c|}
\hline \multirow{2}{*}{ Characteristic } & \multicolumn{2}{|c|}{ Lung Capacity } & \multirow{2}{*}{$\begin{array}{c}\text { Counts } \\
\text { (n) }\end{array}$} & \multirow{2}{*}{$\begin{array}{c}\text { Percents } \\
(\%)\end{array}$} & \multirow{2}{*}{$\mathbf{p}$} \\
\hline & Normal & Abnormal & & & \\
\hline \multicolumn{6}{|l|}{ Age (years) } \\
\hline $19-25$ & 3 & 16 & 19 & 45,2 & \\
\hline $26-30$ & 3 & 6 & 9 & 21,4 & \\
\hline $31-35$ & 1 & 0 & 1 & 2,4 & 0,157 \\
\hline $36-40$ & 2 & 5 & 7 & 16,7 & \\
\hline $41-45$ & 0 & 6 & 6 & 14,3 & \\
\hline \multicolumn{6}{|l|}{ Gender } \\
\hline Male & 7 & 23 & 30 & 71,4 & 0,634 \\
\hline Female & 2 & 10 & 12 & 28,6 & \\
\hline \multicolumn{6}{|l|}{ Body Mass Index } \\
\hline Underweight & 0 & 7 & 7 & 16,7 & \\
\hline Normal & 2 & 14 & 16 & 38,1 & 0,140 \\
\hline Overweight & 4 & 6 & 10 & 23,8 & \\
\hline Obese & 3 & 6 & 9 & 21,4 & \\
\hline \multicolumn{6}{|l|}{ Self Protection } \\
\hline \multicolumn{6}{|l|}{ Devices } \\
\hline Allways & 3 & 2 & 5 & 11,9 & \\
\hline Seldom & 6 & 17 & 23 & 54,8 & 0,014 \\
\hline Never & 0 & 14 & 14 & 33,3 & \\
\hline \multicolumn{6}{|l|}{$\begin{array}{l}\text { Working Periods } \\
\text { (vears) }\end{array}$} \\
\hline $1-5$ & 7 & 20 & 27 & 64,3 & \\
\hline
\end{tabular}




\begin{tabular}{lllcll}
\hline $6-10$ & 1 & 9 & 10 & 23,8 & 0,575 \\
$11-15$ & 1 & 4 & 5 & 11,9 & \\
\hline
\end{tabular}

Table 2. Correlation of workplace and lung capacity of Petrol Gas Station Workers

\begin{tabular}{|c|c|c|c|c|c|c|c|}
\hline \multirow[t]{2}{*}{ Workplace } & \multicolumn{2}{|c|}{$\begin{array}{l}\text { Lung Capacity } \\
\text { Normal }\end{array}$} & \multicolumn{2}{|c|}{$\begin{array}{l}\text { Lung Capacity } \\
\text { Abnormal }\end{array}$} & \multicolumn{2}{|c|}{ Total } & \multirow[t]{2}{*}{$\mathrm{p}^{*}$} \\
\hline & $\mathrm{N}$ & $\%$ & $\mathrm{~N}$ & $\%$ & $\mathrm{~N}$ & $\%$ & \\
\hline Outdoor & 1 & 3,1 & 31 & 96,9 & 32 & 100 & 0,000 \\
\hline Indoor & 8 & 80,0 & 2 & 20,0 & 10 & 100 & \\
\hline
\end{tabular}

According to the data above, showed 31 of 32 respondents $(96,9 \%)$ have abnormal lung capacity in outdoor and 2 of 10 respondents $(20 \%)$ at outdoor. P value $0,00(\mathrm{p}<0,05)$, so there was a signifficant correlation of workplace and lung capacity of Petrol Gas Station workers ( $p$ value $=0,00$ ).

The aim of the research were to investigate the association of workplace and lung capacity of the workers. Many researches state the correlation of air pollutant to decline lung function. Environmental pollution is one of the major problems facing humanity and other kind of life in the world recently. Environmental pollution is defined as "the contamination of the physical and biological hazard of the atmosphere system to such an extent that normal environmental processes are adversely affected. Any use of natural resources more than nature's capacity to restore itself can result in pollution of air, water, and land [6]. The decline in environmental quality as a consequence of pollution is evidenced by loss of vegetation, biological diversity, excessive amounts of harmful chemicals in the ambient atmosphere and in food grains, and growing risks of environmental accidents and threats to life support systems. Pollution is viewed from different angles by different people but is commonly agreed to be the outcome of urban-industrial and technological revolution, elevated of exchange of matter and energy, accelerated industrial wastes. The substances that cause pollution can be any chemical (toxic metal, radionuclides, organophosphorus compounds, gases) or physical substance (heat, radiation, sound wave) that is released by man into the environment. Based on the nature of pollutants the pollution may be categorized as follows: Air Pollution, Water Pollution, Soil/Land Pollution, Noise Pollution, radioactive Pollution and Thermal Pollution. Among them, air pollution is the main type impact to the environment, humans, plants, animals, and all living organisms [7].

The major air pollutant i.e. particulate matter, ozon, nytrogen oxides, carbon monoxide and sulfur dioxide. Particles $>10 \mu \mathrm{m}$ make it pass the upper airways and small particles $<2,5 \mu \mathrm{m}$ can pass in alveoli. Fine particles store in distal airways can cause acute respiratory disease, decreased lung function. Ozone is formed by photochemical reaction of volatile organic compound contribute to lung irritation and inflammation, impaired pulmonary function and nose, eye and throat irritation in which neutrphils and inflammatory cytokines increased. Nitrogen oxide from 
motor vehicles can causes emphysema, increased airway reactivity and succeptible to infection at the animal. Carbon monoxide can impact to anaemia and reduces oxygen carrying capacity [8].

The respiratory system is recognized to be critical for toxicity of nitric oxides from outdoor. Dissolving Nitric dioxide (NO2) and nitric oxide with water contained in the bronchial mucus, form nitric acid and nitrous acid. The acids may influences produce acute pulmonary injury due to inhalation of vapors and gases originating from nitric acid solutions. Nitric oxides in the level very high concentrations can cause immediate death, toxic pulmonary edema within 48 hours, pneumonia, or acute respiratory distress syndrome. The result of chronic exposure to nitric oxides can be fibrous chronic bronchitis, diffuse interstitial lung fibrosis with emphysema, and bronchial hyperreactivity. It was documented that chronic occupational exposure to nitric oxides is correlated with increased susceptibility to respiratory infections and with changes in spirometric indices [9].

The effect of wood dust and copper mine airborn exposures to workers has been shown to cause several respiratory disorders such as impairment of lung function [9] [10]. Airborne exposures to irritants, dusts, and gases can cause pulmonary function (PF) impairment during high-level acute conditions, as well as prolonged periods of low-dose exposure for workers. For occupations that cause potential uncontrolled exposure to substances known to be associated with PF impairment, respirators may be the principal method for exposure control [11].

A patient with obstructive lung disease experiences more difficulty emptying the lungs than filling them. The lung capacity is normal but the functional residual capacity (FRC) and the residual volume increased, so the vital capacity is reduced. As the result, The FEV1/VC\% is much lower than normal $(80 \%)$ ). In contrary to obstructive lung disease, the residual volume in restrictive lung disease is usually normal [3].

\section{Conclusion}

Furthermore, the conclusion is the abnormal lung capacity can caused by air pollutan i.e. sulfur dioxides, carbon monoxide, ozon nytrogen oxides and other particulate matters leading to the impaired the lung function. Its recommended to the workers to protects the lung by using Protection devices in order to avoid the impairment of lung function.

\section{References}

[1] World Health Organization: Ambient air pollution: Health impacts, 2019.

[2] Hulke, S. M., Patil, P. M., Thakare, A. E. \& Vaidya, Y. P. Lung function test in petrol pump workers. Natl. J. Physiol. Pharm. Pharmacol. 2, 71, 2012.

[3] Sherwood, L. Introduction to human physiology. (Brooks/Cole Cengage Learning, 2013.

[4] Panis, L. I. et al. Short-term air pollution exposure decreases lung function: a repeated measures study in healthy adults. Environ. Heal. 16, 60, 2017.

[5] Paulin, L. \& Hansel, N. Particulate air pollution and impaired lung function. F1000 Research 5, 201, 2016.

[6] Krishna, I. V. M., Manickam, V., Shah, A. \& Davergave, N. Environmental management: science and engineering for industry. (Butterworth-Heinemann, 2017.

[7] Rai, P.K. Biomagnetic Monitoring of Particulate Matter: In the Indo-Burma Hotspot Region (Elsevier, , 2015. 
[8] Maji, A. Air Pollution and Lungs. J. Assoc. Chest Physicians 6, 1, 2018.

[9] Skoczynska, A. et al. Association between the Type of Workplace and Lung Function in Copper Miners. Biomed Res. Int, 2016.

[10] Mc Cluskey, James D et al. "Occupational health surveillance: Pulmonary function testing in emergency responders." Journal of emergencies, trauma, and shock vol. 7,3, 2014.

[11] Baran, S. Et al. Lung function: occupational exposure to wood dust. Eur. J. Med. Res. 347, 2141-214, 2009. 